International Journal of Language Education

Volume 5, Number 4, 2021, pp. 356-371

ISSN: $2548-8457$ (Print) 2548-8465 (Online)

Doi: https://doi.org/10.26858/ijole.v5i4.23590

\title{
Cultural Discourse in Reading Texts of Indonesian Language Proficiency Test
}

\author{
Dessy Wahyuni \\ Universitas Gadjah Mada, Indonesia \\ Email:dewahyuni77@gmail.com \\ Yeni Maulina \\ Balai Bahasa Provinsi Riau, Indonesia \\ Email:ymaulina@gmail.com
}

Agus Mulia

Balai Bahasa Provinsi Sumatera Utara, Indonesia

Email: agusmulia2020@gmail.com

Sunardi

Badan Pengembangan dan Pembinaan Bahasa, Indonesia

Email: sunardi.sun8@gmail.com

Received: 16 September 2021

Reviewed: 29 September 2021-25 November 2021

Accepted: 5 December 2021

\begin{abstract}
Foreign students studying in Indonesia are enhancing from year to year. As students who do not use their first language in communicating, both in learning and in social relationships, their ability to speak Indonesian requires to be tested. It is essential in order to ensure the continuity of the learning that will be passed. Consequently, the government owing to the Language Development and Cultivation Agency has established an Indonesian Language Proficiency Test (UKBI [Uji Kemahiran Berbahasa Indonesia]), which is a standardization test for proficiency in the language of Indonesian speakers, both native and foreign speakers. Despite being a tool to measure Indonesian language skills, UKBI also has the prospect to be utilized as a medium to encourage the diversity of Indonesian cultures. This effort is considered important to preserve and maintain the identity of the nation from the world's point of view, particularly against the speed of globalization. By observing various cultural elements in the three "reading texts" at UKBI by way of critical discourse analysis, it can be perceived that the three texts have the opportunity to defend the Indonesian language and culture. Furthermore, due to the test results of 30 foreign students in UKBI in Indonesia, foreign students' understanding and knowledge of the diversity of Indonesian languages and cultures were revealed.
\end{abstract}

Keywords: UKBI; critical discourse analysis; reading; culture; foreign students 


\section{Introduction}

As a country that has seven hundreds of regional languages with various ethnic groups (Bahasa, 2021), Indonesia committed Indonesian as the language of unity on October 28, 1928 (Youth Pledge). This is reinforced by the presence of Law Number 24 of 2009 concerning the Flag, Language, and National Emblem, as well as the National Anthem of Article 25 paragraph 2 which states that the Indonesian language functions as a national identity, national dignity, a mean of unifying various ethnic groups, as well as a mean of communication among regions and regional cultures.

As a strategic country in various fields (political, economic, social, and cultural fields), it is not remarkable that Indonesia is in demand by other nations, for all parts such as in the political, economic, social, and cultural, and even language fields. Primarily, when Indonesia initiates itself to the implementation of free markets with the hope of increasing the economic growth of the country and society, many foreigners come to this country. The development of the free market affects not only the Indonesian economy, but also the language and culture of the nation through the rapid growth of industrial performers, equally from inside and outside the country. Language as a medium of communication and culture as the identity of a group is likely to be contaminated, especially by performers from outside the local culture.

That is the fact that we often observe nowadays. Indonesian is being stroked by a shift in the roles and functions of the speakers of this language. It can be seen when the proliferation of foreign languages - especially English, which is perceived as having more value than the national language and regional languages - ranges from advertisements, types of business, shop names, to shopping center names.

In a determination that foreign languages and cultures will not affect the national identity, the government and society collaborate in efforts to maintain the national identity in various life stages. In order to prevent language and culture that increasingly confronted in the hustle and bustle of modern life, the government through Badan Pengembangan dan Pembinaan Bahasa (Language Development and Cultivation Agency) is taking an important role by launching the Indonesian Language Proficiency Test (Uji Kemahiran Berbahasa Indonesia [UKBI]). As standardization of language proficiency tests, UKBI is expected to be able to be applied as a means of maintaining the nation's language and culture simultaneously.

UKBI emerges as an effort to defend Indonesia's national identity. Besides being able to maintain Indonesian on the world stage, UKBI also is expected to develop the existence of the nation's culture which is increasingly eroded by foreign influences. This determination can be carried out by presenting cultural discourse in the questions tested at UKBI.

UKBI, which is existing as an upholder of Indonesian language and culture, is intended not only for native speakers, but also for foreign speakers. This prospect should be used as a momentum for the construction of the culture of the nation through language, for both native and foreign speakers. The prospects for cultural construction can be elevated through the social realm contained in UKBI (Ismadi et al., 2019).

So, does the material presented in UKBI convey cultural discourse?

In order to observe cultural discourse in the material in UKBI, the research team analyzed various cultural elements conveyed through the "reading" text, because in that part, the realm of society often appears. Furthermore, reading is also related to the intellectual development of the reader (Patiung, 2016) which is considered appropriate as the expected identity construction medium. Intellectual development which is related to critical thinking skills is really needed in this competitive 21st century (Sultan et al., 2018). 
In this study, three texts were analyzed from three different UKBI batteries. The three texts were tested on 30 participants, each text was written by 10 participants. The thirty participants are foreign students (from various countries) who are currently pursuing higher education in Indonesia. By applying Norman Fairclough's critical discourse analysis, the text, discourse practice, and social practice were analyzed. By way of critical discourse analysis, the potential depth of the three discourses in UKBI to be agents of identity construction for foreign students studying in Indonesia will be observed.

\section{Literature review}

Identifying ideology in a discourse is not something abstract. It is a concrete activity that is a social practice (Qazi and Shah, 2018). Ideology is perceived as a way to place oneself as a social subject. In this context, Norman Fairclough (1995a) attempts to construct discourse theory as a critique of existing theories. By observing linguistic, interpretative, and sociological aspects, Norman Fairclough (1995a) offers a discourse model that covers three dimensions, specifically text, discourse practice, and social practice. Each of these dimensions has its own area, process, and analysis model. These three dimensions are associated dialectically. Additionally, Fairclough (1995a) formulates the concept of intertextuality which encourages the interrelation of various texts and discourses in a text. Moreover, this concept also produces an ideological impact in the form of structuring and restructuring the existing discourse order. When ideology is embedded in discourse, intertextuality acts as a mechanism to maintain or change domination relations (Thibault, 1993; Widdowson, 1996; Fowler, 1997; Fairclough et al., 2002; Fairclough, 2008; Hwia, 2010; Ulinnuha et al., 2013; Fairclough, 2013b; Munfarida, 2014; Aziz, 2017).

Critical discourse analysis based on Fairclough's view applies three-dimensional analysis, explicitly (1) textual analysis at the micro-level, that is a description of the text; (2) analysis of discourse practice at the meso-level, that is the interpretation of the process of generating, disseminating, and using discourse, including intertextuality and interdiscursivity; and (3) analysis of socio-cultural practices at the macro level, specifical explanations of hidden social processes in discourse (Fairclough, 1992; Fairclough, 1995b; Rogers et al., 2005; Wodak and Meyer, 2009; Badara, 2012; Fram, 2013). Therefore, the text is related to linguistics which provides a description of linguistic features in revealing the nativity manifestation of the text to obtain the description that is presented; discourse practice deals with the process of producing and consuming text which indicates the interpretation of the relationship between the discourse process and the text which analyzes the process until the text can be read and interpreted by the reader. Besides text, context also influences this type of analysis, both situational and intertextual context; and social practice related to contexts outside the text as an explanation between discourse and sociocultural reality which is oriented to describe discourse that is part of social practice. This explanation also indicates discourse's determination of social structures and their reproductive effects on these structures, both the effect of establishing and changing existing structures (Fairclough, 2005). Therefore, by applying a critical approach, discourse analysis not only examines linguistic aspects, but also recounts them to contexts that are associated with specified goals and practices (Wahyuni and Maulina, 2020).

The research team applied a three-dimensional framework in the critical discourse analysis proposed by Norman Fairclough, in order to observe the efforts of the Language Development and Cultivation Agency in constructing cultural discourse in the UKBI issue in order to strengthen the nation's identity. Consequently, the three texts in the reading section on three different batteries in UKBI are applied as the data to be studied. 


\section{Language and culture as national identity}

Culture generates humans have a limit value in thinking, behaving, and acting. Culture is always in the realm of reason and conscience, providing every human being the strength to filter bad things from life. Culture is result of goodness of human mind in social life. Besides, according to Koentjaraningrat (2009), culture is a whole system of ideas, actions, and human work in people's lives that belong to humans by learning. Hence, it can be concluded that culture is only possessed by human society; not received biologically but obtained through the learning process; and attained, supported, and passed on by humans as members of society. There are 7 universal elements of culture, specifically the language system, knowledge, kinship or social organization, tools of life and technology, economy or livelihoods, religion, and art.

Meanwhile, the storm of globalization as an indication of modernization is occurring in Indonesia. Several thought patterns, attitudes, and behaviors as present-day manifestations affect behavior and language. The foreign cultural intervention has contributed to the diminishing existence of Indonesia's diverse culture. As consequence of the emergence of this phenomenon, the Indonesian language is highly required for its role as the unifier of the nation. The friction of change that affects the foundations of the national life must not damage the basic values of the Indonesian state. As a unifier of unity and integrity, the Indonesian language can eliminate the boundaries of ethnicity and cultural diversity of the Indonesian people in communicating.

In the life of the nation and state, Indonesian has a stable position and function. In this stability, Indonesian is undergone rapid development so that it is a language not only capable of unifying national unity and integrity but also as a carrier of knowledge. Indonesian has been able to accommodate a variety of concepts of knowledge, both concepts rooted in the wisdom of the archipelago and the concept of Western civilization. Language is also one of the factors encouraging the progress of the nation due to the fact that it is a means of opening insights to developing science and technology.

Language, as a form of one's speech, is the main identity of the ethnic group. Language behavior is a description of the situation and condition of the ethnic group. Language is a defender of culture. By means of language, messages, meanings, and cultural values are conveyed. Hence, language that is confused and confusing, will also produce confused thoughts. This unclear mind is what triggers bad cultural behavior.

Language determines not only the character of culture, but also the human way of thinking. Therefore, a nation with a different language will have a different cultural style and way of thinking. Because language affects the culture and way of thinking of humans, the characteristics that exist in a language will be reflected in the attitudes, behavior, and culture of the speakers.

In this globalization era, when information technology appears to be a king in human multiactivities, language is progressively inferior. The function of language is not more than just as a meaningless means of communication. Definitely, this fact endangers the existence of humans as social beings (Wahyuni, 2017). The implication is that language loses its semantic, aesthetic, and sociolinguistic meaning. As a matter of fact, the three of them imply the cultural meanings that are able to create a positive contribution to a more civilized society.

As Indonesian, we should be delighted with the development of the Indonesian language. This language is not only the official language of the Indonesian state but also the second official language in Vietnam, which was officially announced in December 2007 (Dwi et al., 2016; Hang, 2018). Furthermore, Indonesian is also learned by more than 45 countries in the world, such as Australia, America, Canada, Vietnam, and many other countries. 
The rapid development of the Indonesian indicates a stronger national identity. The high interest of foreigners in learning Indonesian and culture should be embraced positively. Hence, the expectation of our nation that intends to encourage Indonesian towards the international world indicates a bright spot. For this reason, according to Hasanah et al. (2021), the foreign students in Indonesia must be introduced to local culture. So, they can recognize the various cultures that exist in Indonesia.

\section{Research method}

In this study, the research team analyzed the dialectical relationship between semiotics in text and other elements in social practice which were described through textual, discourse practice, and social practice analysis through reading texts in Section III UKBI. The data used are words, phrases, clauses, and grammar in the text as a representation of the construction of cultural discourse on UKBI questions to strengthen national identity. The data in this study were obtained from the three texts in Section III: Reading, the second part consisting of 8 questions (questions number 9-16) on different batteries, explicitly batteries A, B, and C. The three texts are considered to encompass seven cultural elements which conveyed by Koentjaraningrat due to the fact that it contained a social discourse. Meanwhile, the participants in this study were 30 foreign students who will or are continuing their higher education in Indonesia. The students are from various countries, specifically Thailand, Sudan, Vietnam, China, Japan, Malaysia, South Korea, and Tanzania. Each of the ten participants completed a text problem reading from 3 different batteries. Based on the research of Sultan \& Fitri (2020) who said that reading behavior is influenced by internal and external factors, the research team took receptors from various countries with different genders and ages.

In collecting data, both at the textual level, discourse practice, and social practice, the research team pays attention to the seven elements of culture that are promoted by Koentjaraningrat (2009) in each text. The seven elements of culture are the system of language, knowledge, kinship or social organization, equipment of life and technology, economy or livelihood, religion, and the arts.

The collecting data at the textual level is focused on choosing the correct words with a certain grammar. In this case, there are several things that need to be considered, such as identifying patterns of use of words and phrases that represent Indonesian culture, identifying the type of process and participants used in the clause and classifying them based on the type of transitivity process. For data collection, at the discourse level, what must be considered is the identification of general ideas associated with the practice of discourse in the three reading texts which are applied as data sources. The data to be analyzed in the practice of discourse must take into consideration of the Indonesian government as the text producers and foreign students as UKBI participants. The readability of discourse in a text is largely determined by three main factors, namely the text, the writer, and the reader (Sultan et al., 2020). At this stage, the process of producing and distributing the text must also be considered. The correlation between the various levels in the text, as well as the institutional position, knowledge, intentions, values, and interests of the recipients of the text, should not go unnoticed. On the other hand, for data collection at the level of social practice, the research team recorded relevant data regarding the acquisition of discourse through various elements of Indonesian regional culture included in the three texts. Then, the data that was taken into account were the results of the Indonesian language proficiency test through tests conducted by foreign students from various countries. 
The data analysis used in this study applied the three-stage method described by Fairclough, specifically description, interpretation, and explanation. These three stages aim at elucidating the dialectical relationship between semiotics in the text and other elements in social practice (Haryatmoko, 2017). For the description stage, what is carried out is to analyze the research data based on the discourse textuality of the three texts at the level of words, clauses, and sentences associated with their respective uses in representing Indonesian culture. In the second stage, explicit interpretation is carried out by analyzing research data that focuses on discourse interpretation. This stage focuses on the point of agreement between what is in the minds of reading text makers as producers and what is in the minds of UKBI participants as text consumers. This point of agreement is mediated by depending on the institutional position, knowledge, intentions, values, and interests of producers and receptors. The last stage is the explanation. At this stage, the social processes that shape discourse in research are elucidated. This is carried out as an instrument with the objective of escalating awareness and offering changes to the receptors for the better. For this purpose, it is necessary to examine three elements in the meaning process, specifically the Indonesian government, UKBI, and foreign students as producers, mediators, and receptors.

\section{Result and discussion}

The "Reading Text" in the Indonesian language proficiency test (UKBI)

Indonesian plays an important role in various fields. Consequently, it is compulsory to have regulations related to the use of language in these various fields. The stipulation of these regulations - directly or indirectly-makes proficiency in Indonesian in the interest of many parties. Proficiency in Indonesian has begun to be the main requirement in the world of education and career development. Therefore, institutions for learning and testing Indonesian proficiency have existed in various countries.

Corresponding to that, the Language Development and Cultivation Agency, Ministry of Education and Culture, arranged an instrument for evaluating Indonesian proficiency which was then standardized by the term UKBI (Uji Kemahiran Berbahasa Indonesia) or Indonesian Language Proficiency Test. The stipulation of UKBI as a Standard Test of Language Proficiency in Peraturan Menteri Pendidikan dan Kebudayaan (Ministry of Education and Culture Regulation) Number 70 of 2016 is a breakthrough in the implementation of Law Number 24 of 2009 on the Flag, Language, and National Emblem, as well as the National Anthem.

UKBI is a test instrument which designed and developed to measure the proficiency of Indonesian of spoken and written Indonesian speakers. UKBI is only a proficiency test for general purposes, not an achievement test, by applying a criterion-referenced measurement, specifically the use of Indonesian in the reality of Indonesian speakers (UKBI Team of Language Agency of Riau Province, 2021). There are several groups of language skills test sections, explicitly Section I: Listening, Section II: Responding to Grammar, Section III: Reading, Section IV: Writing, and Section V: Speaking. The distribution of UKBI material accompanied by the number of questions and time required for testing are as the following (Ismadi et al., 2019).

Table 1 UKBI Material Distribution and Implementation Time

\begin{tabular}{llll}
\hline Section & $\begin{array}{l}\text { The Number } \\
\text { Questions }\end{array}$ & of Time & Information \\
\hline Section I (Listening) & 40 items & 30 minutes & \\
\hline
\end{tabular}




\begin{tabular}{|c|c|c|c|}
\hline $\begin{array}{l}\text { Section II } \\
\text { (Responding to } \\
\text { Grammar) }\end{array}$ & 25 items & 20 minutes & $\begin{array}{l}\text { Written questions in the form of } \\
\text { sentences to which the participant } \\
\text { responded by choosing a } \\
\text { replacement option for the wrong } \\
\text { part. }\end{array}$ \\
\hline $\begin{array}{l}\text { Section III } \\
\text { (Reading) }\end{array}$ & 40 items & 45 minutes & $\begin{array}{l}\text { There are } 5 \text { written discourses. } \\
\text { Each discourse consists of } 8 \\
\text { questions. }\end{array}$ \\
\hline $\begin{array}{l}\text { Section IV } \\
\text { (Writing) }\end{array}$ & 1 item & 30 minutes & $\begin{array}{l}\text { Written questions in the form of } \\
\text { requests to present } \\
\text { pictures/diagrams/ tables in a } \\
\text { written discourse of } 200 \text { words. }\end{array}$ \\
\hline $\begin{array}{l}\text { Section V } \\
\text { (Speaking) }\end{array}$ & 1 item & 15 minutes & $\begin{array}{l}\text { Written questions in the form of } \\
\text { requests to present } \\
\text { pictures/diagrams/ tables in oral } \\
\text { discourse for } 5 \text { minutes of } \\
\text { preparation and } 10 \text { minutes of } \\
\text { presentation. }\end{array}$ \\
\hline Section I-III & 105 items & 95 minutes & \\
\hline Section I-IV & 106 items & 125 minutes & \\
\hline Section $\mathrm{I}-\mathrm{V}$ & 107 items & 140 minutes & \\
\hline
\end{tabular}

(Source: Ismadi et al., 2019)

The material in each section of UKBI which is sourced from the use of Indonesian in everyday life comprises of various domains such as the realm of communication, science, cognitive dimensions, and knowledge. In the realm of communication, there are four types of discourse, such as a survivor discourse in the form of personal communication for the benefit of being in a public place; social discourse in the form of interpersonal communication to establish and enhance cooperation, as well as express ideas and concerns; vocational discourse in the form of productive behavior, such as telling a process, sequence of steps, characteristics, and tips for doing something that is productive; and academic discourse (found at a higher level) in the form of a description of awareness of communicating about scientific behavior to develop knowledge (Yance, 2017; Ismadi et al., 2019).

The utilization of UKBI has accessed various fields with various needs, including foreign students who intend to continue their study in Indonesia. The certificate of completion of the Indonesian proficiency test is one of the three main requirements for foreign students who will continue their study in Indonesia. It is stated in the Regulation of the Minister of Research and Technology and Higher Education of the Republic of Indonesia Number 2 of 2015 on the Admission of New Undergraduate Students at State Universities in Chapter IV of paragraph 3 of Foreign Citizen Student Admissions (Sunendar, 2017). This Indonesian proficiency certificate can be obtained by foreign students through UKBI.

Dominantly, cultural discourse is enclosed in one of the five discourses contained in Section III (Reading) in the social realm. Material about culture is often found in the second discourse (questions number 9-16) in the reading section.

Reading is supposed to be a process in obtaining messages and information that plays a role in intellectual development (Patiung, 2016). Reading, as a language skill, is an activity of obtaining information, enhancing insight, and increasing thinking power through receptive writing (Muzdalifah et al., 2019). Every human being should have reading skills because it is included as 
a basic skill that occupies a crucial role in life. Reading is a process of recording various texts in discourse that are associated with the reader's knowledge to form meaning (Kurniaman and Noviana, 2021).

Reading is not an activity of understanding short-term memory, but it is an understanding for a long period of time (long term memory). Storage and understanding in the long term will make readers to be critical so as to they can obtain meaningful messages from the information acquired. The results of such readings will have a weight on the daily activities of the readers in the form of changes in attitudes, behavior and actions, either directly or indirectly. It cannot be detached from the readability of the text. The higher the readability of a text, the greater the impact is and vice versa (Puspita, 2017).

Therefore, by constructing cultural discourse on the test material in the reading section, it is expected that UKBI participants will expand an understanding of Indonesian culture. UKBI participants who accomplish critical reading will indicate changes in attitudes, behavior, and actions towards the culture that is the identity of the Indonesian nation.

\section{Cultural element in "Reading Text" in UKBI}

Overall, the three texts in UKBI that are used as data, encompass the seven cultural elements that proposed by Koentjaraningrat. Text A, for example, contains the commemoration of a religious holiday in one of the regions in Indonesia. Text B contains the traditional ceremony of a village in eastern Indonesia. Meanwhile, text $\mathrm{C}$ contains a folk song in Indonesia.

In order to observe the various elements of culture that include in the text of batteries A, $\mathrm{B}$, and $\mathrm{C}$, Fairclough's critical discourse analysis through 3 dimensions is applied, explicitly textual, discourse practice, and social practice analysis. In this analysis, the language in the text is used as a tool in a comprehensive explanation of a social context by involving various aspects outside of language in the methodological process. A description of the seven universal elements of culture found in the reading text in batteries A, B, and C is as the following.

The language system contained in the three texts indicates the value of language in writing which is accustomed to the socio-cultural context in the three referred areas. The language system existed in the three texts indicates a means of fulfilling human social needs in interacting with others. The language system indicates a symbolic system in communicating among certain communities. In battery A, the language system is stated at the celebratory naming terms. In Bengkulu, it is called the Tabot Ceremony, while in other areas, with almost similar activities, the naming will also be different (for example the Tabut Ceremony: West Sumatra). In battery B, the language system appears in the traditional ceremonial term, specifically sweeping strokes, and the name of the oil for treating wounds, namely tasala. In battery C, the language system is found in the song title, namely "Rasa Sayange", which is the local language of Maluku.

The knowledge system is manifested in human ideas which involve human knowledge of the various elements that play a role in life. In battery A, the knowledge system appears in the habits of the Bengkulu people who hold a traditional ceremony every Muharram $1^{\text {st }}$ of Islamic New Year. This ceremony eventually undergoes a shift to a festival that does not reduce its sacred meaning. In battery B, the community's knowledge system in Mamala Village, Ambon Island, is appeared in the community's understanding that the traditional hitting ceremony is a symbol of the struggle against Dutch colonial rule. In battery $\mathrm{C}$, the knowledge system refers to the song "Rasa Sayange" which is considered a farewell song at the end of the program.

The kinship and social organizations systems in the form of human efforts to form society through various social groups are governed by norms and customs. In battery A, the kinship and social organization systems are indicated through the origin of the Tabot ritual in Bengkulu, that 
is from the workers who came from Madras, India, who built the Fort Marlborough, as well as the notification that the Tabot celebration in Bengkulu was first carried out by Sheikh Burhanuddin. In battery B, the kinship and social organization system is able to be observed the contents of the text which states that the sweeping ceremony is only followed by men, from teenagers to grandparents, who usually have kinship.

In battery $\mathrm{C}$, the kinship and social organization systems refer to the inheritance of the song "Rasa Sayange" which was passed down from generation to generation as a social song for the Maluku people.

Equipment and technology systems are means of maintaining survival through various elements of technology used in society. In battery A, the system of equipment and technology refers to the ark itself. In battery B, the system of equipment and technology appears in the tasala, which is oil especially made for ceremony participants. In battery $\mathrm{C}$, the system of equipment and technology can be observed in the lyrics of the song "Rasa Sayange".

The economic or livelihood system is the effort of a community group to fulfill various needs in life. In batteries A, B, and C, the economic system that occurs in the lives of the people of Bengkulu, Mamala Village, and Maluku is not particularly visible due to the fact that what is existed in the three texts is a form of regional culture in the form of ritual activities.

The religious system is closely associated with public belief which indicates the relationship between humans and invisible beings (supernatural). In battery A, the religious system can be perceived in the people's belief in commemorating the Prophet Muhammad's grandson, Husein bin Ali bin Abi Talib, who passed away in a battle in Karbala, Iraq. In battery B, the religious system is perceived in the community's belief in the power of tasala oil in treating the wounds of the participants of the sweeping ritual. On the other hand, in battery $\mathrm{C}$, the religious system is unnoticeable. The song "Rasa Sayange" which is appointed in the text only indicates its function as a social song in society.

The final cultural element is an art. The art element indicates that in a society, there are various artistic activities in the form of objects or artifacts, music, or motion arts. This art is comprehended through an element that is highlighted in the text regarding the song "Rasa Sayange" on the battery C.

Through the critical discourse analysis carried out by Norman Fairclough, both in the form of textual, discourse practice, and social practice analysis, it is understood that the three reading texts in 3 UKBI batteries show cultural elements proclaimed by Koentjaraningrat. Thus, it can be said that UKBI can play an active role in introducing Indonesian culture to participants, both genuine and foreign. Thus, UKBI, which participates in promoting Indonesia through cultural discourse, can also function as an agent for maintaining Indonesian language and culture.

Foreign Student Reading Skills

Table 2 The Data of Foreign students in UKBI

\begin{tabular}{|c|c|c|c|c|c|c|c|c|c|c|c|c|c|}
\hline \multirow{2}{*}{ No } & \multirow{2}{*}{ Name } & \multirow{2}{*}{$\begin{array}{c}\text { Country of } \\
\text { Origin }\end{array}$} & \multirow{2}{*}{$\begin{array}{c}\text { The Date of } \\
\text { Test }\end{array}$} & \multirow{2}{*}{$\begin{array}{l}\text { Age } \\
\text { (year) }\end{array}$} & \multicolumn{8}{|c|}{ The Answers of The Questions } & \multirow{2}{*}{$\begin{array}{c}\text { The } \\
\text { Correct } \\
\text { Answers }\end{array}$} \\
\hline & & & & & 9 & 10 & 11 & 12 & 13 & 14 & 15 & 16 & \\
\hline 1 & PA-1 & Thailand & 6 March 2017 & 24 & $\mathrm{~S}$ & $\mathrm{~S}$ & $\mathrm{~B}$ & $\mathrm{~S}$ & $\mathrm{~S}$ & $\mathrm{~S}$ & $\mathrm{~S}$ & $\mathrm{~S}$ & 1 \\
\hline 2 & LA-2 & Sudan & 6 March 2017 & 32 & $\mathrm{~B}$ & $\mathrm{~S}$ & $\mathrm{~S}$ & $\mathrm{~S}$ & $\mathrm{~B}$ & $\mathrm{~B}$ & $\mathrm{~S}$ & $\mathrm{~B}$ & 4 \\
\hline 3 & LA-3 & Thailand & 6 March 2017 & 24 & $\mathrm{~S}$ & $\mathrm{~S}$ & $\mathrm{~S}$ & $\mathrm{~S}$ & $\mathrm{~S}$ & $\mathrm{~S}$ & $\mathrm{~B}$ & $\mathrm{~S}$ & 1 \\
\hline
\end{tabular}




\begin{tabular}{|c|c|c|c|c|c|c|c|c|c|c|c|c|c|}
\hline 4 & LA-4 & Vietnam & 9 March 2017 & 23 & $\mathrm{~S}$ & $\mathrm{~S}$ & $\mathrm{~S}$ & $\mathrm{~S}$ & $\mathrm{~S}$ & $\mathrm{~S}$ & $\mathrm{~B}$ & $\mathrm{~S}$ & 1 \\
\hline 5 & PA-5 & Vietnam & 9 March 2017 & 24 & $\mathrm{~S}$ & $\mathrm{~S}$ & $\mathrm{~S}$ & $\mathrm{~S}$ & $\mathrm{~S}$ & $\mathrm{~B}$ & $\mathrm{~S}$ & $\mathrm{~S}$ & 1 \\
\hline 6 & PA-6 & Vietnam & 9 March 2017 & 22 & $\mathrm{~S}$ & $\mathrm{~S}$ & $\mathrm{~B}$ & $\mathrm{~S}$ & $\mathrm{~S}$ & $\mathrm{~S}$ & $\mathrm{~S}$ & $\mathrm{~S}$ & 1 \\
\hline 7 & LA-7 & Malaysia & 9 March 2017 & 22 & B & $\mathrm{S}$ & $\mathrm{S}$ & $\mathrm{S}$ & $\mathrm{B}$ & $\mathrm{B}$ & $\mathrm{S}$ & $\mathrm{S}$ & 3 \\
\hline 8 & PA-8 & China & 9 March 2017 & 36 & $\mathrm{~S}$ & $\mathrm{~S}$ & $\mathrm{~S}$ & $\mathrm{~S}$ & $\mathrm{~S}$ & $\mathrm{~S}$ & $\mathrm{~B}$ & $\mathrm{~S}$ & 1 \\
\hline 9 & PA-9 & Japan & 9 March 2017 & 22 & $\mathrm{~S}$ & $\mathrm{~B}$ & $\mathrm{~S}$ & $\mathrm{~S}$ & $\mathrm{~B}$ & $\mathrm{~B}$ & $\mathrm{~S}$ & $\mathrm{~S}$ & 3 \\
\hline 10 & LA-10 & China & $\begin{array}{l}22 \text { March } \\
2017\end{array}$ & 25 & $\mathrm{~S}$ & $\mathrm{~B}$ & $\mathrm{~S}$ & $\mathrm{~S}$ & $\mathrm{~B}$ & $\mathrm{~S}$ & $\mathrm{~S}$ & B & 3 \\
\hline 11 & LB-11 & China & 11 July 2017 & 23 & $\mathrm{~B}$ & $\mathrm{~S}$ & $\mathrm{~S}$ & $\mathrm{~B}$ & $\mathrm{~S}$ & $\mathrm{~S}$ & $\mathrm{~S}$ & $\mathrm{~S}$ & 2 \\
\hline 12 & LB-12 & China & 11 July 2017 & 24 & $\mathrm{~B}$ & $\mathrm{~S}$ & $\mathrm{~S}$ & $\mathrm{~B}$ & $\mathrm{~S}$ & $\mathrm{~S}$ & $\mathrm{~S}$ & $\mathrm{~S}$ & 2 \\
\hline 13 & LB-13 & China & 11 July 2017 & 23 & B & $\mathrm{S}$ & $\mathrm{S}$ & $\mathrm{B}$ & $\mathrm{S}$ & $\mathrm{B}$ & $\mathrm{S}$ & $\mathrm{S}$ & 3 \\
\hline 14 & LB-14 & China & $\begin{array}{l}27 \text { March } \\
2018\end{array}$ & 36 & B & $\mathrm{S}$ & $\mathrm{S}$ & $\mathrm{S}$ & $\mathrm{S}$ & $\mathrm{S}$ & $\mathrm{S}$ & $\mathrm{S}$ & 1 \\
\hline 15 & PB-15 & China & $\begin{array}{c}27 \text { March } \\
2018\end{array}$ & 35 & $\mathrm{~S}$ & $\mathrm{~S}$ & $\mathrm{~S}$ & $\mathrm{~S}$ & $\mathrm{~S}$ & $\mathrm{~B}$ & $\mathrm{~S}$ & $\mathrm{~S}$ & 1 \\
\hline 16 & PB-16 & China & $\begin{array}{c}11 \text { December } \\
2018\end{array}$ & 24 & $\mathrm{~S}$ & $\mathrm{~S}$ & $\mathrm{~S}$ & $\mathrm{~S}$ & $\mathrm{~S}$ & $\mathrm{~B}$ & $\mathrm{~S}$ & $\mathrm{~S}$ & 1 \\
\hline 17 & LB-17 & $\begin{array}{l}\text { South } \\
\text { Korea } \\
\end{array}$ & 7 August 2018 & 52 & $\mathrm{~S}$ & $\mathrm{~S}$ & $\mathrm{~S}$ & $\mathrm{~S}$ & $\mathrm{~B}$ & $\mathrm{~B}$ & $\mathrm{~B}$ & $\mathrm{~S}$ & 3 \\
\hline 18 & LB-18 & $\begin{array}{l}\text { South } \\
\text { Korea }\end{array}$ & 7 August 2018 & 57 & B & $\mathrm{S}$ & $\mathrm{S}$ & $\mathrm{S}$ & $\mathrm{S}$ & $\mathrm{S}$ & $\mathrm{S}$ & $\mathrm{S}$ & 1 \\
\hline 19 & PB-19 & $\begin{array}{l}\text { South } \\
\text { Korea } \\
\end{array}$ & $\begin{array}{c}18 \text { December } \\
2018 \\
\end{array}$ & 49 & B & $\mathrm{S}$ & $\mathrm{S}$ & $\mathrm{S}$ & $\mathrm{B}$ & $\mathrm{B}$ & $\mathrm{S}$ & $\mathrm{S}$ & 3 \\
\hline 20 & LB-20 & $\begin{array}{l}\text { South } \\
\text { Korea }\end{array}$ & $\begin{array}{l}18 \text { December } \\
2018\end{array}$ & 18 & $\mathrm{~S}$ & $\mathrm{~S}$ & $\mathrm{~S}$ & $\mathrm{~S}$ & $\mathrm{~S}$ & $\mathrm{~B}$ & $\mathrm{~B}$ & $\mathrm{~B}$ & 3 \\
\hline 21 & LC-21 & Tanzania & 6 June 2017 & 27 & $\mathrm{~B}$ & $\mathrm{~S}$ & $\mathrm{~S}$ & $\mathrm{~S}$ & $\mathrm{~S}$ & $\mathrm{~S}$ & $\mathrm{~S}$ & $\mathrm{~B}$ & 2 \\
\hline 22 & PC-22 & Thailand & 23 May 2017 & 24 & $\mathrm{~B}$ & $\mathrm{~S}$ & $\mathrm{~S}$ & $\mathrm{~B}$ & $\mathrm{~S}$ & $\mathrm{~B}$ & $\mathrm{~S}$ & $\mathrm{~S}$ & 3 \\
\hline 23 & PC-23 & Vietnam & 23 May 2017 & 23 & $\mathrm{~B}$ & $\mathrm{~S}$ & $\mathrm{~S}$ & $\mathrm{~S}$ & $\mathrm{~S}$ & $\mathrm{~S}$ & $\mathrm{~B}$ & $\mathrm{~S}$ & 2 \\
\hline 24 & PC-24 & $\begin{array}{l}\text { South } \\
\text { Korea }\end{array}$ & 23 May 2017 & 23 & $\mathrm{~S}$ & $\mathrm{~S}$ & $\mathrm{~S}$ & $\mathrm{~S}$ & $\mathrm{~B}$ & $\mathrm{~B}$ & $\mathrm{~B}$ & $\mathrm{~B}$ & 4 \\
\hline 25 & PC-25 & $\begin{array}{l}\text { South } \\
\text { Korea }\end{array}$ & 23 May 2017 & 21 & B & $\mathrm{S}$ & $\mathrm{S}$ & $\mathrm{S}$ & $\mathrm{S}$ & $\mathrm{S}$ & $\mathrm{S}$ & $\mathrm{B}$ & 2 \\
\hline 26 & PC-26 & $\begin{array}{l}\text { South } \\
\text { Korea }\end{array}$ & 23 May 2017 & 52 & $\mathrm{~S}$ & $\mathrm{~S}$ & $\mathrm{~S}$ & B & $\mathrm{B}$ & $\mathrm{S}$ & $\mathrm{S}$ & B & 3 \\
\hline 27 & PC-27 & Thailand & 23 May 2017 & 24 & $\mathrm{~S}$ & $\mathrm{~S}$ & $\mathrm{~S}$ & $\mathrm{~S}$ & $\mathrm{~S}$ & $\mathrm{~S}$ & $\mathrm{~S}$ & $\mathrm{~S}$ & 0 \\
\hline 28 & PC-28 & Thailand & 23 May 2017 & 24 & $\mathrm{~S}$ & $\mathrm{~B}$ & $\mathrm{~S}$ & $\mathrm{~S}$ & $\mathrm{~B}$ & $\mathrm{~S}$ & $\mathrm{~B}$ & $\mathrm{~B}$ & 4 \\
\hline 29 & PC-29 & Thailand & 23 May 2017 & 28 & $\mathrm{~S}$ & $\mathrm{~S}$ & $\mathrm{~B}$ & $\mathrm{~S}$ & $\mathrm{~S}$ & $\mathrm{~S}$ & $\mathrm{~S}$ & $\mathrm{~S}$ & 1 \\
\hline 30 & PC-30 & Thailand & 23 May 2017 & 26 & $\mathrm{~S}$ & $\mathrm{~B}$ & $\mathrm{~S}$ & $\mathrm{~S}$ & $\mathrm{~S}$ & $\mathrm{~S}$ & $\mathrm{~S}$ & B & 2 \\
\hline
\end{tabular}

In this study, to observe the reading skills of foreign students who were UKBI participants, 30 participants from various countries were analyzed, specifically 7 students from Thailand, 1 student from Sudan, 4 students from Vietnam, 8 students from China, 1 student from Japan, 1 student from Malaysia, 7 student from South Korea, and 1 student from Tanzania, 17 women and 13 men. The age of the participants also varied: 18 years 1 student; 20 -29 years 21 students; 30 39 years 4 students; 40 -49 1 student; and 50s 3 students. 
The thirty participants worked on 3 different battery questions, each ten students worked on 1 battery of UKBI questions in different processing times. However, what is analyzed in this study is the processing of questions in section III of the second part (question numbers 9-16) which is in the social domain (community). The data for the thirty participants can be seen in the table 2 .

Based on the table, PA and LA, PB and LB, as well as PC and LC, in the participant column indicates that each participant works on a different battery of questions. PA is a female participant working on battery A, while LA is a male participant working on battery A. PB is a female participant working on battery $\mathrm{B}$, while LB is a male participant working on battery $\mathrm{B}$. Then, PC is a female participant working on battery $\mathrm{B}$. Battery $\mathrm{C}$, while $\mathrm{LC}$ is a male participant who works on battery C. PA or LA-1-10 are 10 participants who work on battery A, PB or LB-11-20 are 10 participants who work on battery $\mathrm{B}$, and $\mathrm{PC}$ or LC-21-30 are 10 participants working on battery C. Participants working on battery A consist of 5 women and 5 men from Thailand, Sudan, Vietnam, Malaysia, Japan, and China. Participants who worked on battery B consisted of 3 women and 7 men from China and South Korea. On the other hand, participants who worked on battery C consisted of 9 women and 1 man from Tanzania, Thailand, Vietnam, and South Korea. The groups of participants for each battery also range in age ranges.

From Table 2, it can be implied that country of origin, age, and gender do not affect the correct choice of the participants in answering the questions. It can be perceived that in the participants' answers to questions number 9 to 16 (B for correct answers and $\mathrm{S}$ for wrong answers). PA-1 and LA-3 for example, the two participants are from Thailand, but with different genders. Both of these participants only answered 1 question correctly. Other examples are the PB-19 and LB-20. The two participants are from South Korea with different genders, but both gave 3 correct answers to the questions contained in battery B. They are also in different age ranges, PB-19 is 49 years old and LB-20 is 18 years old, but their average ability is identical in answering reading text questions on UKBI.

The average number of participants who answered correctly on the questions in the reading text, whether battery A, B, or C, did not reach $30 \%$. The group of participants who answered correctly on battery A was only $24 \%$, battery B was $25 \%$, while battery C was $29 \%$. The following is the percentage of the distribution of correct answers for each battery in the social or social domain reading texts in UKBI.

In battery A, questions number 9, 10, 11, and 16 were only answered correctly each by 2 students; question number 15 was answered correctly by 3 students; and questions number 13 and 14 were answered correctly by 4 students. On the other hand, no one is able to answer question number 12 correctly. In battery B, questions 11 and 12 were only answered correctly by 1 student each; question number 14 was answered correctly by 2 students; questions number 9, 10, 13, and 16 were answered correctly by 3 students; while question number 15 was only answered correctly by 4 students. On battery C, question number 11 was answered correctly by only 1 person; 2 people answered questions number 10,12, and 14; and questions 13 and 15 were answered correctly by 3 people; and in question number 9, there is 1 person who answered correctly. Meanwhile, question number 16 was answered correctly by 6 students. This was the only question that was answered correctly by more than $50 \%$. 
Table 3. Correct Answers in the UKBI Reading Text

\begin{tabular}{cccccccccc}
\hline $\begin{array}{c}\text { Question } \\
\text { Number }\end{array}$ & 9 & 10 & 11 & 12 & 13 & 14 & 15 & 16 & Average \\
\hline Battery A & $20 \%$ & $20 \%$ & $20 \%$ & $0 \%$ & $40 \%$ & $40 \%$ & $30 \%$ & $20 \%$ & $24 \%$ \\
\hline Battery B & $30 \%$ & $30 \%$ & $10 \%$ & $10 \%$ & $30 \%$ & $20 \%$ & $40 \%$ & $30 \%$ & $25 \%$ \\
\hline Battery C & $40 \%$ & $20 \%$ & $10 \%$ & $20 \%$ & $30 \%$ & $20 \%$ & $30 \%$ & $60 \%$ & $29 \%$ \\
\hline
\end{tabular}

In considering the preparation of UKBI question material, in addition to being based on the realm of communication which refers to various fields of science, it is also based on the cognitive dimension (Bloom's taxonomy) which has several levels of thought processes, explicitly remembering, understanding, analyzing, and evaluating (Ismadi et al., 2019). These four levels of the thinking process are also found in questions 9-16 in Section III: Reading.

In question number 12 battery A, what is in question is the function of holding the Tabot Festival. If it is analyzed further, this question is at the level of analysis, due to find out the function of the festival requires the ability to describe the reasons for the conversion of the Tabot Ceremony to a festival. In this case, the ability to associate and organize some of the parts contained in the text is required so that it obtains the overall meaning.

Besides to number 12 on battery A which cannot be answered correctly by each participant, there are also 3 other questions that only 1 student is able to answer correctly. This problem is found in battery B number 11 and 12 and battery $\mathrm{C}$ number 11 .

Question number 11 and 12 of battery B, if they are analyzed profoundly, are included in higher-order thinking processes, that is at the level of analysis due to the fact that the ability to organize the various parts that are interrelated in the text is required to obtain meaning. Meanwhile, question number 11 of battery $\mathrm{C}$, after being observed, appear to be not part of the higher-order thinking process. The question is still at the level of understanding in the thought process. In order to prove that the song "Rasa Sayange" originates from Maluku, participants can ensure it by reading the first and second sentences in the second paragraph, which are as the following: The song "Rasa Sayange" is originated from Maluku. This song has been passed down from generation to generation as a social song for Maluku people. Consequently, to answer question number 11, participants simply required to count on their memory.

On the other hand, the only question that was answered correctly by $60 \%$ of the participants was question number 16 on battery $\mathrm{C}$, which is finding the right information based on the text presented. If it is analyzed, this question fits the highest level of the thought process, specifically evaluating. This level is above analyzing, which is the final ability to analyze in critical thinking processes so that participants can determine something correctly. In making these decisions, participants are considered to have succeeded in finding the advantages and disadvantages of the text so that they can provide new ideas. Hence, the participant is considered to have comprehended the text comprehensively.

By observing the ability of foreign students in answering reading texts in Section III UKBI with an average of below $30 \%$ who answered correctly for each text, brings up a question: is the cultural promotion message to be conveyed to foreign students able to be conveyed properly?

However, by observing the development of foreign participants' abilities in completing reading texts on the UKBI for each battery is able to resolve the anxiety. In battery A, for example, the percentage of participants who answered correctly was only $24 \%$. On battery B, this percentage 
increases, though insignificantly, to $25 \%$. Moreover, on battery $\mathrm{C}$, the percentage increases quite a bit, specifically to $29 \%$ (provided that the build and launch times of batteries A, B, and C were gradual). However, what was exciting was that 6 out of 10 participants answered questions on the battery. This question can be expected to be the final question because it refers to the participants' whole understanding, explicitly finding the right information in the text presented thoroughly.

It indicates that the participants have thoroughly understood the contents of the text. Thus, it can also be stated that the cultural discourse carried by reading texts can be conveyed well to foreign students who continue their education in Indonesia. By understanding reading information, it means that they have made good use of short-term memory, which is expected, this memory will move to long term memory. If these memories have touched their long-term memory domain, it is expected that the informative messages about the cultural discourse can encourage themselves up through changes in attitudes, behaviors, and actions of the participants. Thus, the design of UKBI as a determination to preserve Indonesian language and culture will produce the expected results.

Therefore, through the critical discourse analysis arranged by Fairclough, it is possible to reveal cultural constructions in reading texts at UKBI. Through three dimensions of critical discourse analysis, namely textual analysis, discourse practice, and social practice, those cultural elements carried by the reading text can be described. These various elements of culture can be a medium to construct the expected identity.

\section{Conclusion}

UKBI is designed as a medium that is able to reinforce not only the position of language, but also Indonesian culture. This determination was constructed by performing a discourse on the nation's culture through the material contained in UKBI. By reading or listening to the available discourses, UKBI participants - either directly or indirectly - have undergone the cultural constructions that were presented.

Owing to the analysis of critical discourse stated by Norman Fairclough with three dimensions, specifically textual, discourse practice, and social practice analysis, it can be comprehended that the reading text contained in Section III of the second part, question numbers 9-16, has raised 6 of the 7 cultural elements that carried by Kontjaraningrat, explicitly the system of language, knowledge, kinship or social organization, tools of life and technology, religion, and art. The economic system or livelihoods are not included in the text because the UKBI materials only include rituals that exist in the community.

Nevertheless the percentage of foreign students' ability in solving problems correctly in Section III numbers 9-16 is still below 30\%, a change for the better always occurs for each battery. This indicates that the discourse that is conveyed on each question presented is easier to understand. This understanding is very important for foreign students, particularly those that related to cultural messages as the content of information in each text. Through understanding language as well as culture, critical foreign students are believed to be able to experience changes in attitudes, behavior and actions.

Texts with high readability in UKBI have the potential to be a subtle form of discrimination against foreign students regarding language and culture which is the identity of the Indonesian nation. By means of UKBI, Indonesian language and culture which are tripped over by the current of globalization have begun to expose. Therefore, the language and culture that is published through the text in UKBI conducts Indonesian language and culture to the international access as reinforcement of national identity. 
Declaration of conflicting interest

The authors state that there is no conflict of interest among authors to declare concerning the publication of this paper.

Funding acknowledgement

The authors received no financial support for the research, authorship, and/or publication of this article.

\section{References}

Aziz, A. (2017). "Representasi Aktor dan Peristiwa Sosial dalam Krisis Politik di Suriah oleh AlJazeera Arabic dan Al-Jazeera English (Tinjauan Analisis Wacana Kritis)." Universitas Gadjah Mada. http://etd.repository.ugm.ac.id/index.php?mod=penelitian_detail\&sub=PenelitianDetail\&a $\mathrm{ct}=$ view\&typ=html\&buku_id=129577\&obyek_id=4

Badara, A. (2012). Analisis Wacana: Teori, Metode, dan Penerapannya pada Wacana Media. Kencana Prenada Media Group.

Bahasa, B. P. dan P. (2021). Data Bahasa di Indonesia. Petabahasa.Kemdikbud.Go.Id. https://petabahasa.kemdikbud.go.id/databahasa.php

Dwi, F. R., Intan, R., \& Santoso, L. W. (2016). Aplikasi Editor Pemeriksa Ejaan dan Rekomendasi Kata dalam Bahasa Indonesia Berbasis Android. Jurnal Infra, 4(1), 1-6. http://publication.petra.ac.id/index.php/teknik-informatika/article/view/4087

Fairclough, N. (1995a). Critical Discourse Analysis: The Critical Study of Language. Longman.

Fairclough, N. (1995b). Media Discourse. The Hodder Headline Group.

Fairclough, N. (2005). "Discourse Analysis in Organizational Studies: The Case for Critical Realism." Organization $\quad$ Studies, 26(6), 915-939. https://doi.org/10.1177/0170840605054610

Fairclough, N. (2006). Discourse and Social Change (11th ed.). Polity Press.

Fairclough, N. (2008). An Interview with Norman Fairclough. In Comunicação Pública (Vol. 3, $\begin{array}{lllll}\text { Issue } & 6, & \mathrm{p} & \mathrm{h} & \mathrm{http}: / / \mathrm{proxy}-\end{array}$ remote.galib.uga.edu/login?url=http://search.ebscohost.com/login.aspx?direct=true\&db=ed o\&AN $=36072717 \&$ site $=$ eds-live

Fairclough, N. (2013). Critical Discourse Analysis and Critical Policy Studies. Critical Policy Studies, 7(2), 177-197. https://doi.org/http://dx.doi.org/10.1080/19460171.2013.798239

Fairclough, N., Jessop, B., \& Sayer, A. (2002). “Critical Realism and Semiosis.” Journal of Critical Realism, 5(1), 2-10. https://doi.org/https://doi.org/10.1558/aleth.v5i1.2

Fowler, R. (1997). "Review: Norman Fairclough, Critical Discourse Analyisis The Critical Study of Language, London Longman, 1995 Pp XIII, 265.” Language in Society, 26(3), 421—423. https://doi.org/10.1017/S0047404500019539

Fram, S. M. (2013). "The Constant Comparative Analysis Method Outside of Grounded Theory." The Qualitative $\quad$ Report, 18 (Article 1), 1-25. http://www.nova.edu/ssss/QR/QR18/fram1.pdf

Hang, N. T. T. (2018). Metode Pembelajaran Keterampilan Berbicara Bahasa Indonesia bagi Mahasiswa Vietnam. Prosiding SENASBASA (Seminar Nasional Bahasa Dan Sastra), 2(1), 252-259. http://research-report.umm.ac.id/index.php/SENASBASA

Haryatmoko, J. (2017). Critical Discourse Analysis (Analisis Wacana Kritis): Landasan Teori, Metodologi dan Penerapan (H. Zaskuri (ed.); 2nd ed.). Rajawali Pres. 
Hasanah, D. U., Kurniasih, D., \& Halimah, N. N. (2021). Pengembangan Bahan Ajar Keterampilan Membaca Model Graves Mahasiswa BIPA. Ranah: Jurnal Kajian Bahasa, 10(1), 22-38. https://doi.org/https://doi.org/10.26499/rnh.v10i1.1872

Hwia, G. (2010). "Kendali Interaksional sebagai Cerminan Ideologi: Analisis Wacana Kritis Trilogi Drama Opera Kecoa." Jurnal Linguistik Indonesia, 28(1), 11-22. https://doi.org/10.1007/s13398-014-0173-7.2

Ismadi, H. D., Ibrahim, G. A., Syarfina, T., Amalia, D., \& Maryanto. (2019). Pedoman Uji Kemahiran Berbahasa Indonesia (p. 87). Badan Pengembangan dan Pembinaan Bahasa. https://rumahpusbin.kemdikbud.go.id/datapusbin/564_PEDOMAN_UKBI.pdf

Koentjaraningrat. (2009). Pengantar Ilmu Antropologi. Rineka Cipta.

Kurniaman, O., \& Noviana, E. (2021). Metode Membaca SAS (Struktural Analitik Sintetik) dalam Meningkatkan Keterampilan Membaca Permulaan di Kelas I SDN 79 Pekanbaru. Primary: Jurnal Pendidikan Guru Sekolah Dasar, 10(1), 149-157. https://doi.org/http://dx.doi.org/10.33578/jpfkip.v5i2.3705

Munfarida, E. (2014). “Analisis Wacana Kritis dalam Perspektif Norman Fairclough.” Komunika: Jurnal Dakwah Dan Komunikasi, $\quad 8(1), \quad 1-19$. https://doi.org/http://dx.doi.org/10.24090/kom.v8i1.746

Muzdalifah, E., Putri, H. P. H., Novianti, M., Anggi, N., \& Winiyanti, T. (2019). Sastra Dongeng dalam Pempelajaran Membaca Pemahaman. Proceeding Universitas Pamulang, 1(2), 306310. http://openjournal.unpam.ac.id/index.php/Proceedings/article/view/4106

Patiung, D. (2016). Membaca sebagai Sumber Pengembangan Intelektual. Aldaulah: Jurnal Hukum Pidana Dan Ketatanegaraan, 5(2), 352-376. https://doi.org/https://doi.org/10.24252/ad.v5i2.4854

Puspita, A. R. (2017). UKBI untuk Mempertahankan Eksistensi Keindonesiaan (Revitalisasi Budaya Nusantara dalam UKBI). Pengembangan Kemahiran Berbahasa Indonesia, 419427.

https://d1wqtxts1xzle7.cloudfront.net/57981388/Prosiding_ukbi_bADAN_bAHASA.pdf?1 $544641081=\&$ response-content-

disposition=inline \%3B+filename\%3DProsiding_ukbi_bADAN_bAHASA_pdf.pdf\&Expir es $=1615201242 \&$ Signature $=J W-L n d 4 U U K k R k 5 c 6 i c-$

NRlblkZbGL2HBkfTYoZG5dw06pT2qT

Qazi, H., \& Shah, S. (2018). "Identity Constructions Through Media Discourses." Journalism Studies, 19(11), 1597-1612. https://doi.org/10.1080/1461670X.2017.1284574

Rogers, R., Malancharuvil-Berkes, E., Mosley, M., Hui, D., \& Joseph, G. O. (2005). “Critical Discourse Analysis in Education: A Review of the Literature." Review of Educational Research, 75(3), 365-416. https://doi.org/10.3102/00346543075003365

Sultan, \& Fitri, S. (2020). The University Students Online Reading Behavior: Gender, Subject Area, and Academic Achievement in the Digital Era. Asian EFL Journal, 27(4), 276-290. https://doi.org/ISSN : 1738-1460

Sultan, Rapi, M., Mayong, \& Suardi. (2020). Textbook Discourse Readability: Gender, Reading Interest, and Socio-Economic Status of Students With Poor Reading Ability. Cakrawala Pendidikan, 39(3), 583-596. https://doi.org/10.21831/cp.v39i3.32326

Sultan, Rofiuddin, A., Nurhadi, \& Priyatni, E. T. (2018). Development of Mass Media Text-Based Instructional Materials to Improve Critical Reading Skills of University Students. Pedagogika $\quad / \quad$ Pedagogy, $131(3), \quad 26-47$. https://doi.org/http://dx.doi.org/10.15823/p.2018.32 
Sunendar, D. (2017). Kebijakan Kemahiran Berbahasa Indonesia. Pengembangan Kemahiran Berbahasa Indonesia, $1-9$. file://C:/Users/HP/AppData/Local/Temp/MENUMBUHKAN MINAT BACA MASYA RAKAT_GORONTALO_MELALUI_GERAKAN_BUDAYĀ_LITERĀSI_GUNA_MEN GEMBANGKAN_KEMĀHIRAN_BERBAHASA_INDONESIA_Studi_Kasus_di_Keca matan_Tabongo_Kabupaten_Gorontalo.pdf

Thibault, P. (1993). "Review of Norman Fairclough Discourse and Social Change 1992." Social Semiotics, 3(2), 293-310. https://doi.org/10.1080/10350339309384422

Ulinnuha, R., Udasmoro, W., \& Wijaya, Y. (2013). "Critical Discourse Analysis: Theory and Method In Social and Literary Framework." Indonesian Journal of Applied Linguistics, 2(2), 262-274. https://doi.org/https://doi.org/10.17509/ijal.v2i2.170

Wahyuni, D. (2017). Festival Menongkah: Revitalisasi Budaya dan Bahasa Duanu Menuju Industri Kreatif. Kapata Arkeologi, 13(2), 163-178. https://doi.org/https://doi.org/10.24832/kapata.v13i2.407

Wahyuni, D., \& Maulina, Y. (2020). Maintaining The Self-Existence through Short Story "Jalan Sumur Mati." LiNGUA Jurnal Ilmu Bahasa Dan Sastra, 15(2), 149-162. https://doi.org/10.18860/ling.v15i2.9156

Widdowson, H. G. (1996). "Reply to Fairclough: Discourse and Interpretation: Conjectures and Refutations." Language and Literature, 5(1), 57-69. https://doi.org/10.1177/096394709600500106

Wodak, R., \& Meyer, M. (2009). Critical Discourse Analysis: History, Agenda, Theory, and Methodology 1. In Methods for Critical Discourse Analysis (pp. 1-33).

Yance, I. (2017). Peningkatan Sikap Positif terhadap Bahasa Indonesia melalui Materi Uji Kemahiran Berbahasa Indonesia (UKBI). Pengembangan Kemahiran Berbahasa Indonesia, $46-56$.

file:///C:/Users/HP/AppData/Local/Temp/MENUMBUHKAN_MINAT_BACA_MASYA RAKAT GORONTALO MELALUI GERAKAN BUDAYA LITERASI GUNA MEN GEMBAN̄GKAN_KEMĀHIRAN_BERBAHASA_INDONESİA_Studi_Kasus_di_Keca matan_Tabongo_Kabupaten_Gorontalo.pdf. 